\title{
In Reply
}

James YaO, ${ }^{a}$ Diane Reidy Lagunes, ${ }^{b}$ Matthew H. KulKe ${ }^{c}$

${ }^{a}$ The University of Texas MD Anderson Cancer Center, Houston, Texas, USA; ${ }^{b}$ Memorial Sloan-Kettering Cancer Center, New York, New York, USA; 'Dana-Farber Cancer Institute, Boston, Massachusetts, USA

We appreciate the comments of Dr. Steven M. Sorscher regarding our recent publication and the use of targeted agents in neuroendocrine tumors. Neuroendocrine tumors (NETs) exhibit diverse clinical outcomes [1-4]. Several recent studies have demonstrated that tumor histology, which incorporates assessments of tumor differentiation, tumor grade, mitotic rate, and proliferative index, can be associated with clinical outcomes and overall survival [2, 5-7].

The majority of clinical trials to date have been performed in low- or intermediate-grade, well differentiated tumors. High grade, poorly differentiated tumors are widely perceived as being associated with aggressive behavior and a poor prognosis. Patients with such tumors are often treated with platinum-based chemotherapy regimens. The World Health Organization criteria currently define any neuroendocrine tumor with a proliferative index (Ki-67) of $>20 \%$ as high grade (Table 1).

Recently, however, this criterion for defining high-grade tumors has been called into question. In some cases, for example, tumors with a Ki- 67 between $20 \%$ and $50 \%$ may have well differentiated architecture; such tumors will not behave as aggressively as poorly differentiated neuroendocrine carcinomas (NECs). In contrast, tumors with Ki-67 indices of $80 \%-$ $100 \%$ almost universally demonstrated poor differentiation and behave in a manner that parallels pulmonary small cell carcinoma [8]. Such poorly differentiated neuroendocrine carcinomas may in fact possess a non-neuroendocrine cell lineage and be more closely related to a de novo carcinoma [9].

The concept that high-grade tumors (as currently defined) may in fact demonstrate variable clinical behavior has been further supported in a recent study by Sorbye et al., who reviewed data from 305 patients with gastrointestinal poorly differentiated NETs [10]. This study found that response rate to platinum-based chemotherapy was lower in patients with Ki-67 20\%-55\% than in those with a Ki67 >55\% (14\% vs. 44\%, $p<.001)$, although patients with the lower Ki-67 index had longer median survival (15 months) than those with Ki-67 $>55 \%$ (10 months) $(p<.001)$ [10].

Whether targeted agents should be used in some patients with Ki-67 indices of $>20 \%$ is uncertain. Future prospective randomized studies are needed to evaluate whether patients with this group of tumors benefit more from targeted therapy or from a particular cytotoxic regimen.

\section{DISCLOSURES}

James Yao: Ipsen (C/A); Novartis (C/A); Pfizer (C/A); Diane Reidy Lagunes: Novartis (C/A); Pfizer (C/A); Novartis (H); Matthew H. Kulke: Ipsen (C/A); Lexicon (C/A); Novartis (C/A); Pfizer (C/A); Ipsen (RF); Novartis (RF).

(C/A) Consulting/advisory relationship; (RF) Research funding; (E) Employment; (H) Honoraria received; (OI) Ownership interests; (IP) Intellectual property rights/inventor/patent holder; (SAB) Scientific advisory board

Table 1. Grading system for neuroendocrine tumors

\begin{tabular}{llllll}
\hline Differentiation & Grade & Mitotic Count & $\begin{array}{l}\text { Ki-67 } \\
\text { index (\%) }\end{array}$ & Traditional Classification & ENETS, WHO Classification \\
\hline Well-differentiated & Low (G1) & $<2$ per 10 HPF & $\leq 2$ & $\begin{array}{l}\text { Carcinoid, islet cell, } \\
\text { pancreatic } \\
\text { neuroendocrine tumor } \\
\text { Carcinoid, atypical } \\
\text { carcinoid, islet cell, } \\
\text { pancreatic } \\
\text { neuroendocrine tumor }\end{array}$ & $\begin{array}{l}\text { Neuroendocrine tumor, } \\
\text { grade 1 }\end{array}$ \\
& Intermediate (G2) & $2-20$ per 10 HPF & $3-20$ & & $\begin{array}{l}\text { Neuroendocrine tumor, } \\
\text { grade 2 }\end{array}$ \\
Poorly differentiated & High (G3) & $>20$ per 10 HPF & $>20$ & Small cell carcinoma & $\begin{array}{l}\text { Neuroendocrine carcinoma, } \\
\text { grade 3, small cell } \\
\text { Large cell neuroendocrine } \\
\text { Neuroendocrine carcinoma, } \\
\text { grade 3, large cell }\end{array}$ \\
\hline
\end{tabular}

Abbreviations: ENETS, European Neuroendocrine Tumor Society; HPF, high power field; WHO, World Health Organization.

Correspondence: James C. Yao, M.D., Department of Gastrointestinal Medical Oncology, Division of Cancer Medicine, The University of Texas MD Anderson Cancer Center, 1515 Holcombe Boulevard, Houston, Texas 77030, USA. Telephone: 713-792-2828; Fax: 713-563-0539; E-Mail: jyao@mdanderson.org Received July 9, 2013; accepted for publication August 21, 2013. CAlphaMed Press 1083-7159/2013/\$20.00/0 http:// dx.doi.org/10.1634/theoncologist.2013-0242 


\section{REFERENCES}

1. Rindi G, D'Adda T, Froio E. Prognostic factors in gastrointestinal endocrine tumors. Endocr Pathol 2007;18:145-149.

2. Oberg K, Knigge U, Kwekkeboom D et al. Neuroendocrine gastro-entero-pancreatic tumors: ESMO Clinical Practice Guidelines for diagnosis, treatment and follow-up. Ann Oncol 2012;23 Suppl 7: p. vii124-30.

3. Klimstra DS, Modlin IR, Coppola D et al. The pathologic classification of neuroendocrine tu mors: a review of nomenclature, grading, and staging systems. Pancreas 2010;39:707-712.

4. Klimstra DS. Pathology reporting of neuroendocrine tumors: Essential elements for accurate diagnosis, classification, and staging. Semin Oncol 2013;40: 23-36.
5. Oberg K, Jelic S, ESMO Guidelines Working Group. Neuroendocrine gastroenteropancreatic tumors: ESMO clinical recommendation for diagnosis, treatment and follow-up. Ann Oncol 2009;20 Suppl 4:150-153.

6. Ferrone CR, Tang LH, Gonen M et al. Determining prognosis in patients with pancreatic endocrine neoplasms: Can the WHO classification system be simplified? J Clin Oncol 2007;25:5609-5615

7. Ellison TA, Wolfgang $\mathrm{CL}$, Shi C et al. A single institution's 26-year experience with nonfunctional pancreatic neuroendocrine Tumors: A validation of current staging systems and a new prognostic nomogram. Ann Surg 2013 [Epub ahead of print].

8. Moertel CG, Kvols LK, O'Connell MJ et al.
Treatment of neuroendocrine carcinomas with combined etoposide and cisplatin: Evidence of major therapeutic activity in the anaplastic variants of these neoplasms. Cancer 1991;68:227232.

9. Yachida S, Vakiani E, White CM et al. Small cell and large cell neuroendocrine carcinomas of the pancreas are genetically similar and distinct from well-differentiated pancreatic neuroendocrine tumors. Am J Surg Pathol 2012;36:173-184.

10. Sorbye $H$, Wellin S, Langer SW et al. Predictive and prognostic factors for treatment and survival in 305 patients with advanced gastrointestinal neuroendocrine carcinoma (WHO G3): the NORDICNEC study. Ann Oncol 2013;24:152-160. 